\title{
FEEDING AND ABSORPTION IN CERASTODERMA EDULE UNDER ENVIRONMENTAL CONDITIONS IN THE BAY OF MARENNES- OLERON (WESTERN FRANCE)
}

\author{
M.B. URRUTIA*, J.I.P. IGLESIAS*, E. NAVARRO* AND J. PROU ${ }^{+}$
}

*Departamento de Biología Animal y Genética, Facultad de Ciencias, Universidad del País Vasco/Euskal Herriko Unibertsitatea, Apartado 644, E-48080 Bilbao, Spain. 'IFREMER, Station de La Tremblade, UREA, BP 133, F-17390 La Tremblade, France

Physiological processes involved in energy acquisition by the filter-feeding bivalve Cerastoderma edule (L.) (Mollusca: Bivalvia) were quantified under naturally fluctuating feeding conditions imposed by tidal cycles in the Bay of Marennes-Oleron. Physiological measurements were performed during two neap and two spring tidal cycles in order to cover a wide range of seston concentrations (TPM $=15-95 \mathrm{mg} \mathrm{l}^{-1}$ ). The main effect exerted by tides on the food supply was the resuspension of bottom sediments of low organic content, leading to a strong 'dilution' of suspended organic matter.

Although filtration rate was found to increase with seston concentration, ingestion rate was strictly regulated by means of pseudofaeces production. Selection efficiencies for chlorophyll a $\left(\mathrm{SE}_{\mathrm{chl}}\right)$, overall organic matter $\left(\mathrm{SE}_{\mathrm{o}}\right)$, carbon $\left(\mathrm{SE}_{\mathrm{C}}\right)$ and nitrogen $\left(\mathrm{SE}_{\mathrm{N}}\right)$ were estimated and related to dietary descriptors. The following ranking was found for the efficiency with which different substrates were selected: $\mathrm{SE}_{\mathrm{chl}}>\mathrm{SE}_{\mathrm{N}}>\mathrm{SE}_{\mathrm{o}}>\mathrm{SE}_{\mathrm{C}}$. Absorption efficiency was found to depend on the organic content of ingested matter according to an exponential saturating function. Observed differences between carbon and nitrogen absorption efficiency were not statistically significant. Absorption rate was kept fairly constant through the wide range of seston concentrations and qualities.

Sediment resuspension processes may exert important and variable effects on energy acquisition processes depending on the intensity of resuspension events and the quality of the resuspended matter.

\section{INTRODUCTION}

Feeding activity and metabolism of suspension-feeding bivalves are considered key elements of benthic-pelagic coupling in coastal and estuarine systems (Dame, 1993). Given their mode of feeding, dense aggregations of suspension-feeding bivalves are responsible for an impressive flux of matter from the water column to the sea bed. They also contribute significantly to nutrient regeneration and, hence, influence nutrient cycling rates, playing a fundamental role at the ecosystem level.

Characteristics of suspended particles have been demonstrated to affect feeding processes of bivalve molluscs to a considerable extent. Therefore, many studies on feeding physiology were performed using food sources that closely resembled natural particle composition, such as mixtures of sediment particles and phytoplankton (Kiørboe et al., 1981; Bricelj \& Malouf, 1984; Bayne et al., 1987, 1989; Iglesias et al., 1992), detrital 
particles of plant origin derived from vascular plants and macroalgae (Stuart, 1982; Lucas \& Newell, 1984; Newell \& Langdon, 1986; Cranford \& Grant, 1990) or, even, concentrated natural seston obtained by filtration of natural sea-water (de Villiers \& Hodgson, 1993). Most of these experiments were performed in the laboratory where variables can be strictly controlled. However, extrapolation of results obtained in laboratory experiments to food conditions prevailing in the field for the purpose of predicting bivalve feeding behaviour poses serious problems. Such an approach assumes some simplification regarding the quantity, quality and nature of seston particles and the temporal dynamic of suspended matter. Recent studies have therefore analysed the effect of naturally varying seston characteristics on feeding processes under environmental conditions (Stenton-Dozey \& Brown, 1992, 1994; Deslous-Paoli et al., 1992; Newell \& Shumway, 1993; Cranford \& Hargrave, 1994).

In this work, the results obtained from a study performed on the infaunal bivalve Cerastoderma edule in the Bay of Marennes-Oleron, a shallow estuarine embayment are presented. Given the hydrodynamic characteristics of the Bay, resuspension of bottom sediment greatly contributes to the maintenance of very elevated seston loads, with a high proportion of suspended mineral particles (Razet et al., 1990). The area has historically been used for oyster cultivation, but other suspension feeders, such as mussels, cockles and clams, are also present in high densities.

The objectives of the work were: (1) to characterize the feeding behaviour and physiological processes involved in energy acquisition in cockles maintained under natural conditions of food composition and availability, and (2) to obtain mathematical functions relating feeding and absorption rates to characteristics of the food environment. Experiments were performed during four complete tidal cycles, two neap and two spring tides having been chosen to include extreme current speeds. As a result, physiological responses were determined under a wide range of seston concentrations and compositions. Feeding and absorption processes monitored included clearance, filtration, rejection, ingestion and absorption rates, and selection and absorption efficiencies. All these variables were calculated for total particulate matter, particulate organic matter, chlorophyll $a$, and organic carbon and nitrogen.

\section{MATERIAL AND METHODS}

\section{Experimental set-up and cockle collection}

Experiments were performed in 1992, in a small laboratory located at the outer end of the pier at Le Chapus (Marennes-Oleron Bay, Charente Maritime, France) during two neap (27 and 28 May) and two spring (31 May and 1 June) tides. A pump, located at $1 \mathrm{~m}$ above the bottom of the mud-flat, pumped sea-water continuously to a header-tank where particles were maintained in suspension by a magnetic stirrer placed on the bottom. Sea-water was then delivered by a peristaltic pump to 12 small beakers. Individual cockles were introduced into each of ten beakers, while the remaining two were left empty and used as controls. Flow rates through the beakers were maintained at $\approx 100 \mathrm{ml} \mathrm{min}^{-1}$, a rate high enough to ensure that depletion of particle concentration produced by the filtering activity of cockles was kept below $30 \%$ (determined using a 
Coulter Multisizer). Sea-water temperature during experimentation averaged $20 \cdot 1 \pm 0 \cdot 4^{\circ} \mathrm{C}$.

Cockles used in this work were collected in the bay a few days before the experiment started and held in plastic net-bags on a mud-flat close to the field laboratory. When the tide reached the place where cockles had been located in the mudflat, ten individuals were collected and introduced into the beakers. Cockles were fixed with plasticine to the bottom of the beakers, in a position allowing easy collection of biodeposits.

\section{Characterization of suspended matter}

During each tidal cycle, sea-water samples were collected from the outflows of the control beakers at intervals of 1.5-2 h. Three aliquots were taken from every sample and, after recording the volume, were separately analysed for characterization of suspended matter.

The first aliquot was passed through 25-mm Whatman GF/C filters that had been previously washed, labelled, ashed at $450^{\circ} \mathrm{C}$ for $6 \mathrm{~h}$ and weighed to the nearest 0.001 mg. Filters were then rinsed with distilled water to remove salts, dried at $110^{\circ} \mathrm{C}$ for $24 \mathrm{~h}$, weighed, ashed at $450^{\circ} \mathrm{C}$ in a muffle furnace for $6 \mathrm{~h}$ and re-weighed. Following this procedure, concentration of total particulate matter (TPM:mg ${ }^{-1}$ ) and particulate inorganic matter (PIM:mg 1-1) were measured. Particulate organic matter concentration (POM:mg l-1 ${ }^{-1}$ ) was calculated as the difference between TPM and PIM, and the organic content of suspended matter $(f)$ as $f=$ POM/TPM.

The second aliquot was also filtered through GF/C filters and was used for chloropigment determination. Once sea-water had been filtered, $1 \mathrm{ml}$ of magnesium carbonate $(1 \%)$ was added to prevent acidification and then, stored at $-20^{\circ} \mathrm{C}$ in dark tubes until determination of pigment concentration. Chlorophyll $a\left(\mathrm{chl} a: \mu \mathrm{g} \mathrm{l}^{-1}\right)$ and phaeopigment (pha: $\mu \mathrm{g} \mathrm{l}^{-1}$ ) concentrations were established following the Lorenzen (1967) method.

The third aliquot was filtered through pre-ashed $\left(450^{\circ} \mathrm{C}\right) \mathrm{GF} / \mathrm{C}$ filters to determine particulate organic carbon (POC: $\mathrm{mg} \mathrm{l}^{-1}$ ) and nitrogen (PN:mg $\mathrm{l}^{-1}$ ) concentrations in suspended matter. In order to remove inorganic carbon, filters were exposed to concentrated hydrochloric acid vapours and then, stored at $-20^{\circ} \mathrm{C}$ until combustion in a Perkin Elmer 2400 elemental analyser which had been calibrated using acetanilide as standard.

One of the main objectives of the present work was to obtain functional relationships between feeding parameters and seston characteristics. Physiological parameters were therefore related to the different seston variables after integrating (by averaging) discreet measurements (TPM, PIM, POM, chl $a$, POC and PN) over each period of biodeposit collection.

\section{Physiological measurements}

Food processing rates were determined following Iglesias et al. (1992) by measuring biodeposition rates and referring them to the characteristics of suspended matter. This method may be applied when all particles are retained by the gill with similar efficiency and thus, composition of suspended and filtered matter are similar. Cockles retained all particles composing the seston with similar efficiency (own unpublished results), so 
requirements needed for applying this method were fulfilled. Nevertheless, the suitability of the biodeposition method was checked by comparing clearance rates obtained from biodeposition data $\left(\mathrm{CR}_{\text {bior }}\right.$ see below) with clearance rates calculated from particle depletion in the feeding chambers. Every $2 \mathrm{~h}$, particle concentration in the 2-60 $\mu \mathrm{m}$ size range was determined in samples from the outflow of the control $(\mathrm{Cc})$ and experimental chambers (Ce) using a Coulter Multisizer. Clearance rate was calculated according to the expression $\mathrm{CR}_{\text {flow }}=$ flow rate $\left(\mathrm{h} \mathrm{h}^{-1}\right) \times(\mathrm{Cc}-\mathrm{Ce}) / \mathrm{Cc}$. This direct method measured instantaneous clearance rates $\left(\mathrm{CR}_{\text {flow }}\right)$ whereas biodeposition method gave averaged clearance rates $\left(\mathrm{CR}_{\mathrm{bio}}\right)$. To determine the coincidence degree of both methods, $\mathrm{CR}$ data obtained for each experimental cockle by either method were grouped and mean values compared.

After a $2 \mathrm{~h}$ accommodation period at the beginning of the high tide, trays were cleaned of biodeposits. Then, faeces and pseudofaeces for each individual were separately collected at $2 \mathrm{~h}$ intervals; great care was taken to avoid disturbing the animals. Following this protocol, three or four biodeposit samples could be collected during the tidal cycle. Both faecal and pseudofaecal samples were treated as described for seston samples: faeces and pseudofaeces produced by each cockle were homogenized and divided into aliquots that were used for estimating total, organic and inorganic mass, chlorophyll $a$, carbon and nitrogen content. In this way, the following rates were determined: total matter rejection (RR:mg $\mathrm{h}^{-1}$ ); organic matter rejection (ORR:mg $\mathrm{h}^{-1}$ ); inorganic matter rejection (IRR:mg $\mathrm{h}^{-1}$ ); total egestion (defecation) (ER:mg $\mathrm{h}^{-1}$ ); organic matter egestion (OER:mg $\mathrm{h}^{-1}$ ); inorganic matter egestion (IER:mg $\mathrm{h}^{-1}$ ), and rates of rejection and egestion of chlorophyll $a$, POC and PN.

Assuming that absorption of inorganic matter through the digestive system is negligible (Cranford \& Grant, 1990), the sum of IRR and IER was considered to represent the rate of inorganic matter filtration (IFR:mg h $\mathrm{h}^{-1}$ ). Clearance rates (CR:I he were then estimated as CR=IFR/PIM. Filtration rate of total particulate matter (FR:mg $\mathrm{h}^{-1}$ ) was computed as $\mathrm{FR}=\mathrm{CRxTPM}$ and filtration rate of particulate organic matter (OFR:mg h $\mathrm{h}^{-1}$ ) as $\mathrm{OFR}=\mathrm{CR} \times \mathrm{POM}$. Ingestion rates of total (IR:mg h${ }^{-1}$ ), and organic (OIR: $\mathrm{mg} \mathrm{h}^{-1}$ ) particulate matter were estimated as IR=FR-RR and OIR=OFR-ORR, and hence, the organic content of ingested food (i) could be calculated as OIR/IR. The rate of food absorption (AR:mg h${ }^{-1}$ ) was computed as AR=OIR-OER, and absorption efficiency (AE) as AE=AR/ OIR. Similarly, feeding, absorption rates and absorption efficiency $\left(A E_{C}\right.$ and $\left.A E_{N}\right)$ were estimated for carbon and nitrogen.

Preingestive selection efficiencies for both total filtered organic matter $\left(\mathrm{SE}_{\mathrm{o}}\right)$ and filtered chlorophyll $a\left(\mathrm{SE}_{\mathrm{chl}}\right)$ were also estimated as: $\mathrm{SE}_{\mathrm{o}}=1-(\mathrm{p} / \mathrm{f})$ (Navarro et al., 1992) and $\mathrm{SE}_{\mathrm{chl}}=1-(\mathrm{chlp} / \mathrm{chlf})$, where $\mathrm{p}$ is the organic content of the pseudofaeces ( $\mathrm{p}=\mathrm{ORR} /$ $R R$ ), $f$ is, as defined above, the organic content of suspended matter ( $f=P O M / T P M)$, chlp is the chlorophyll $a$ content in the pseudofaeces ( $\mu \mathrm{g} \mathrm{chl} a / \mathrm{mg}$ ) and chlf is the chlorophyll $a$ content in the filtered matter $(\mu \mathrm{g} \mathrm{chl} a / \mathrm{mg})$. Selection efficiencies for carbon $\left(\mathrm{SE}_{\mathrm{C}}\right)$ and for nitrogen $\left(\mathrm{SE}_{\mathrm{N}}\right)$ were similarly estimated by comparing carbon and nitrogen contents in pseudofaeces and in suspended matter. 


\section{Size standardization of physiological rates}

Once the physiological measurements were completed, soft tissues from each cockle were excised, dried at $80^{\circ} \mathrm{C}$ for $48 \mathrm{~h}$ and weighed. Rates were standardized to an equivalent $0.5 \mathrm{~g}$ dry tissue cockle by using the formula $\mathrm{Ys}=\mathrm{Yex}(0.5 / \mathrm{We})^{\mathrm{b}}$, where $\mathrm{Y}_{\mathrm{s}}=$ rate of the standard-sized cockle; $Y e=$ uncorrected physiological rate; We = measured weight of experimental animal $(\mathrm{g})$ and $\mathrm{b}=$ the weight power established for clearance rate of cockles ( $b=0 \cdot 57$, own unpublished results), which has been assumed to represent the size dependence for rates of food processing in general.

\section{Statistical procedures}

To obtain functional relationships between physiological parameters and the characteristics of suspended matter, regression equations were fitted to experimental data, following standard least squares procedures. Where appropriate, data were tested for normality and homoscedascity prior to statistical comparisons. Regression analyses were performed by simple linear, polynomial, multiple linear and non-linear procedures, depending on the kind of function to be fitted in each case. The StudentNewman-Keuls (SNK) test was used to compare selection efficiencies of different substrates. All statistical analyses were performed using the Statview programme for Apple computers, except non-linear regressions, that were fitted by means of BMDP for PC.

\section{RESULTS}

\section{Seston characteristics}

Recorded variations in the concentration of total particulate matter (TPM) in suspension are represented in Figure 1 for the two neap (A) and two spring (B) tidal cycles. Initial concentrations were very high in both kind of tides, due to the resuspension of sedimentary matter that occurred when the tide reached the plot from which sea-water was being pumped. After this peak, seston concentration dropped sharply during the neap tides and relatively low values were recorded at the middle of the cycle (Figure 1A). At spring tides, however, there was a second increase in particle concentration that corresponded to the highest current speeds (Figure 1B). There was a final elevation in seston concentration at the end of all the cycles (not shown for spring tides), as a consequence of the high turbulence produced by the water masses leaving the mud-flat. In general, seston concentrations were higher during spring (30-95 $\mathrm{mg} \mathrm{l}^{-1}$ ) than during neap (15-65 $\left.\mathrm{mg} \mathrm{l}^{-1}\right)$ tides.

As shown in Figure 2A, there was a clear correlation $\left(r=0.8529, \mathrm{~N}=23 P<10^{-4}\right)$ between particulate organic matter (POM) and total particulate matter (TPM) in suspension. Despite this correlation, for rising seston concentrations there was a reduction in the organic content of suspended matter (Figure 2B), indicating that inorganic particles predominated in resuspended matter. Chloropigment concentrations were also variable along the tidal cycles. Chlorophyll $a$ was independent of TPM, while phaeopigment concentration was significantly correlated with total seston (Figure 2C), so it was 


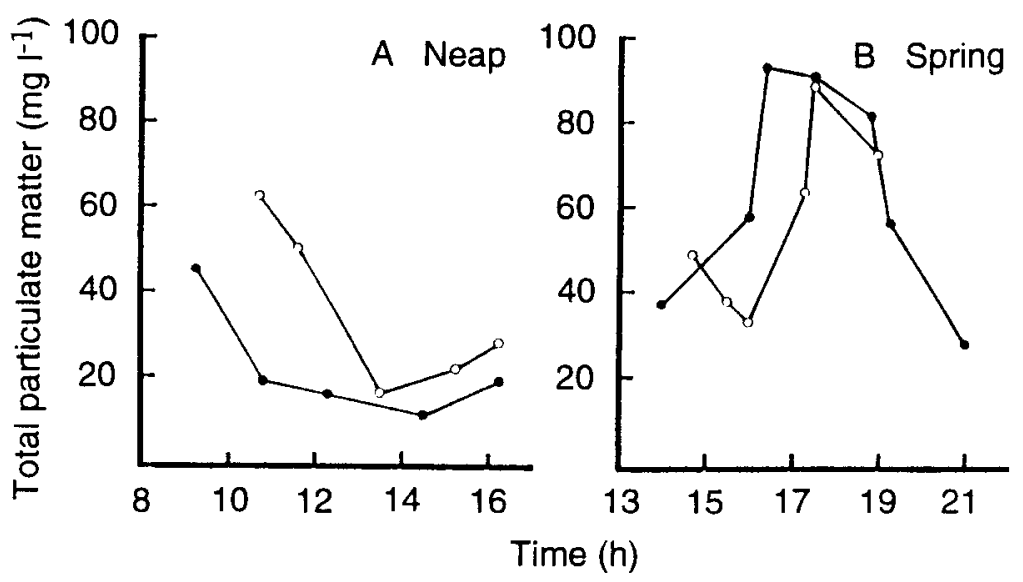

Figure 1. Evolution of total particulate matter (TPM: $\mathrm{mg} \mathrm{I}^{-1}$ ) with time during (A) neap and (B) spring tides. Dates for neap tides were $(\bullet) 27$ May 1992 and $(0) 28$ May 1992; dates for spring tides were $(\bullet)$ 31 May 1992 and (๖) 1 June 1992.

concluded that resuspended matter contained no living phytoplankton, but organic matter degraded from chlorophyll containing particles.

Particulate organic carbon (POC) and nitrogen (PN) availability also increased with rising TPM (Figure 2D). The rate of increase was different for both substrates, however, since $\mathrm{C} / \mathrm{N}$ ratio (by weight) of suspended organic particles was negatively correlated with the organic content of suspended matter (Figure 3A), indicating that the proportion of carbon in seston rose faster than nitrogen with rising TPM. A similar decreasing trend showed in the C:chl ratio (Figure 3B) indicated that resuspended organic matter was mainly of detritic origin.

\section{Validation of the biodeposition method for measuring clearance rates}

For each cockle used in the work, average CR data obtained from particle depletion in the feeding chambers (CRflow) were compared with mean CR values calculated from biodeposition $\left(\mathrm{CR}_{\mathrm{bio}}\right)$. The following regression equation was obtained after statistical fitting of original data:

$$
\mathrm{CR}_{\mathrm{bio}}=0.9536( \pm 0 \cdot 0929) \mathrm{CR}_{\text {flow }}+0.0211 r^{2}=0 \cdot 861 \mathrm{~N}=20 \text {. }
$$

At $P=0.05$ significance level the slope was not different from one, nor was the intercept from zero. Biodeposition method was, thus, validated as a procedure to calculate feeding rates. This method was used for all subsequent calculations since it gives more integrated information.

\section{Filtration, rejection and ingestion rates}

Multiple linear regression was used to obtain functional relationships between feeding rates and characteristics of suspended matter. After such an analysis, (see Table 1) filtration rate (FR) appeared related to total seston concentration (TPM) by means of a 

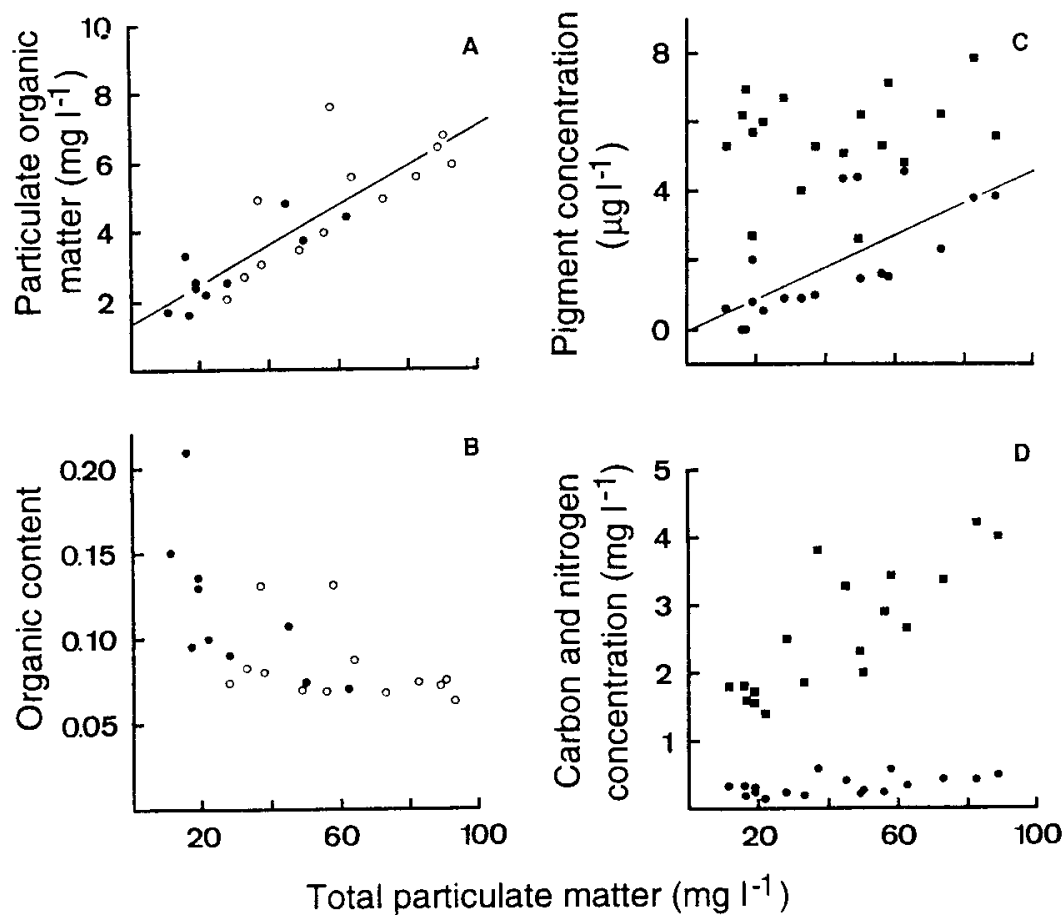

Figure 2. (A) Particulate organic matter concentration (POM: $\mathrm{mg}^{-1}$ ) related to total particulate matter concentration (TPM: $\mathrm{m} \mathrm{I}^{-1}$ ). , sea-water samples collected during spring tides; $\boldsymbol{\theta}$, samples from neap tides. The line corresponds to the equation fitted to individual data: $P O M=1.3562+0.0562$ $( \pm 0.0075)$ TPM; $r^{2}=0.7274, N=23, P=10^{-4}$. (B) Organic content of seston (f) related to total particulate matter concentration (TPM:mg $~^{-1}$ ). Symbols as in (A). (C) $\mathbf{\square}$, Chlorophyll $a$ and $\boldsymbol{\bullet}$, phaeopigment, concentration $\left(\mu \mathrm{g} \mathrm{l}^{-1}\right)$ related to total particulate matter concentration (TPM:mg lited $\mathrm{l}^{-1}$. Fitted regression equations were: $Y=5.07+0.011$ TPM $r^{2}=0.037, N=13, P=0.44$ for chlorophyll $a$, and $Y=-0.07+0.046$ TPM $r^{2}=0.507, N=13, P=0.001$ for phaeopigments. The line corresponds to the fitted equation for phaeopigment. (D) Particulate organic carbon $(\boldsymbol{\nabla}=\mathrm{POC})$ and nitrogen $(\boldsymbol{=}=\mathrm{PN})$ concentration, related to total particulate matter concentration (TPM: $\mathrm{mg} \mathrm{l}^{-1}$ ).

power equation of the form: $\mathrm{FR}=\mathrm{a} \mathrm{TPM}^{\mathrm{b}}$. Total particulate matter appeared as the only parameter significantly affecting filtration rate, explaining $69 \cdot 2 \%$ of its variability. A bvalue significantly higher than 1 obtained for this equation reflects that filtration was not strictly proportional to TPM concentration, but that the effect of this variable was multiplicative; in other words, clearance rate increased with rising particle concentration.

Taking the approach of Kiørboe et al. (1980), rejection rate (RR) was expressed as a linear function of FR. However, and as documented by Iglesias et al. (1996), the degree of dependence between both variables is itself a function of the organic content of suspended matter. Therefore, we entered $f$ in the multiple regression equation relating RR to FR, as well as the interaction term FRxf (see Table 2). In this case $f$ was rejected as it did not reach the required significance level $(P=0 \cdot 05)$, but remaining terms, FR and FRxf, were highly significant, explaining $99.7 \%$ of the variance recorded in RR. The equation predicts that the rate of pseudofaeces production increased linearly with 


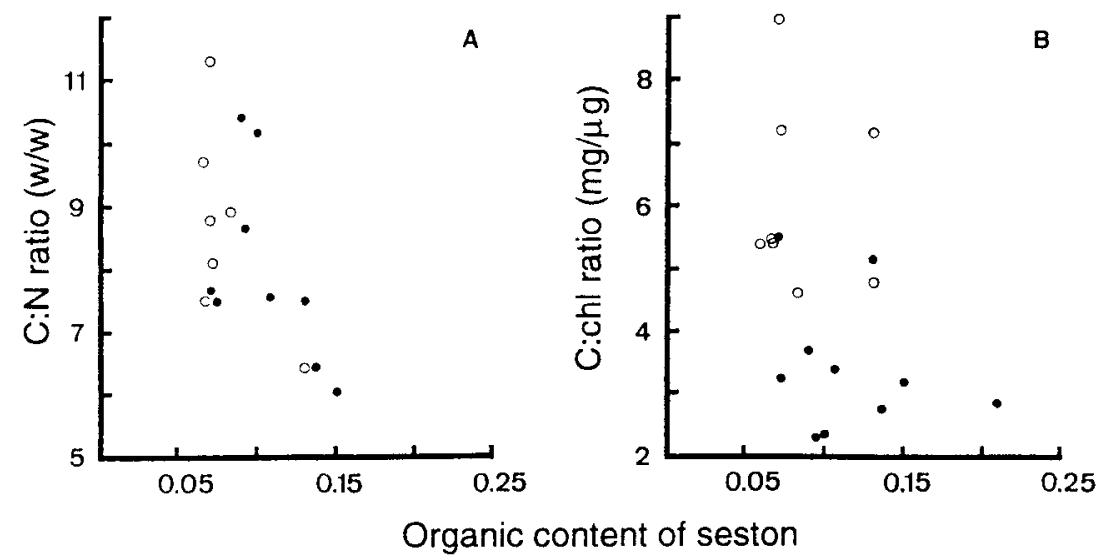

Figure 3. (A) $\mathrm{C} / \mathrm{N}$ ratio and (B) C:chl index measured in sea-water samples collected during neap and () spring tides, in relation to the organic content of the seston.

Table 1. Multiple-regression equation relating Log filtration rate (FR:mg $h^{-1}$ ) to Log total particulate matter (TPM: $m g l^{-1}$ ), seston organic content $(f)$ and the interaction term (LogTPMxf).

\begin{tabular}{lccr}
\multicolumn{1}{c}{ Terms } & Coefficients & Standard Error & F Value \\
Retained terms & -0.194 & & \\
Intercept & 1.197 & 0.071 & 281.361 \\
LogTPM & $r^{2}=0.692$ & d.f. $=126$ & \\
& & & \\
Rejected terms & & & 0.106 \\
f & & & 0.454 \\
LogTPMxf & &
\end{tabular}

filtration rate. On the other hand, rejection rate decreased for increasing organic content of food, as evidenced by the negative sign of the interaction term between FR and $\mathrm{f}$. Thus, for a given filtration rate, the proportion of filtered matter being rejected increased for low organic content of suspended matter.

Table 2. Multiple-regression equation relating rejection rate ( $\left.R R: m_{g} h^{-1}\right)$ to filtration rate (FR:mg $\left.h^{-1}\right)$, seston organic content ( $f$ ) and the interaction term (FRxf).

\begin{tabular}{lccc}
\multicolumn{1}{c}{ Terms } & Coefficients & Standard Error & F Value \\
Retained terms & & & \\
Intercept & -7.544 & 0.018 & \\
FR & 1.040 & 0.251 & 3456.756 \\
FRxf & -1.238 & d.f. $=126$ & 24.4 \\
& $r^{2}=0.997$ & & \\
Rejected terms & & & 0.935
\end{tabular}

Predicted filtration, rejection and ingestion rates have been plotted in Figure $4 \mathrm{~A}-\mathrm{C}$ as a function of TPM. As FR was not found to depend on $\mathrm{f}$, a single curve gives account of observed variability in filtration rate. Two rejection and ingestion rate curves, corre- 
sponding to organic contents of 0.2 and 0.05 , have been plotted. These values are representative of the range recorded in the present experiments. The close proximity of curves representing rejection and filtration rates reveals the quantitative relevance of pseudofaeces production as a component of the overall processing of suspended matter

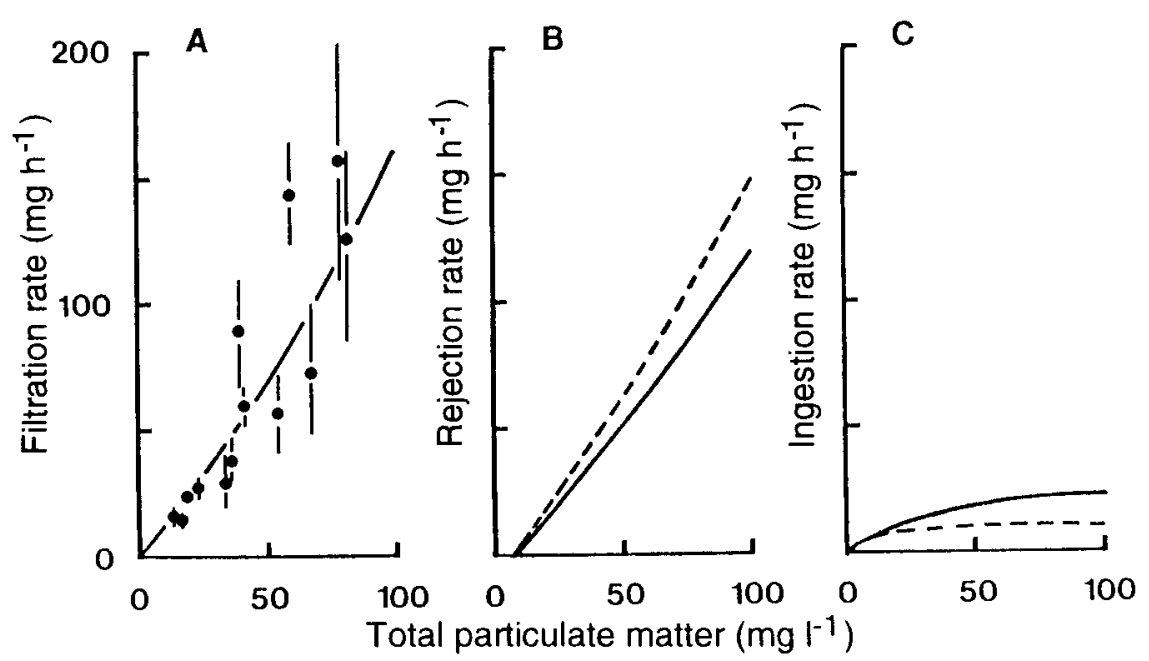

Figure 4. (A) Rates of filtration; (B) rejection and (C) ingestion, measured in $\mathrm{mg} \mathrm{h}^{-1}$, as a function of total particulate matter (TPM:mg l-1 ${ }^{-1}$ ). In (A), mean FR values \pm CI $(95 \%)$ corresponding to different samples have been plotted over the line representing the equation fitted to experimental data (see Table 1). In (B), rejection rates predicted by equation given in Table 2 have been plotted for two extreme values of organic content of seston: $0 \cdot 05$ (broken line) and $0 \cdot 20$ (solid line). In (C) ingestion rates (estimated as the difference FR-RR) corresponding to the same organic contents have been plotted. Broken line, 0.05; solid line, 0.20.

by Cerastoderma edule. Maintenance of IR almost constant at TPM concentration above $10 \mathrm{mg} \mathrm{l}^{-1}$ is evident, owing to increasing pseudofaecal production with rising seston concentration. However, the maximum level reached in this regulation is positively dependent on the organic content of filtered matter.

\section{Preingestive selection}

Following Iglesias et al. (1992), selection efficiencies for both total organics ( $\mathrm{SE}_{\mathrm{o}}$ ) and chlorophyll $a\left(\mathrm{SE}_{\mathrm{chl}}\right)$ have been plotted in Figure $5 \mathrm{~A}$ as a function of the organic content of suspended particles. Second degree polynomials are appropriate to fit these relationships, but we were interested in checking a possible effect of seston concentration on selection efficiencies. Accordingly, individual SE values were fitted with multiple regression equations in which independent terms were $f, f^{2}$ (to account for the hypothetical polynomial dependence of SE on $\mathrm{f}$ ) and TPM as simple variables, and the corresponding interaction terms: TPMxf and TPMxf ${ }^{2}$. Regarding selection efficiency of chlorophyll $a$, TPM was the only factor whose effect (negative) was statistically significant (see Table 3A). Therefore, as particle concentration rose, the efficiency with which chlorophyll $a$ was selected for preferential ingestion decreased. 


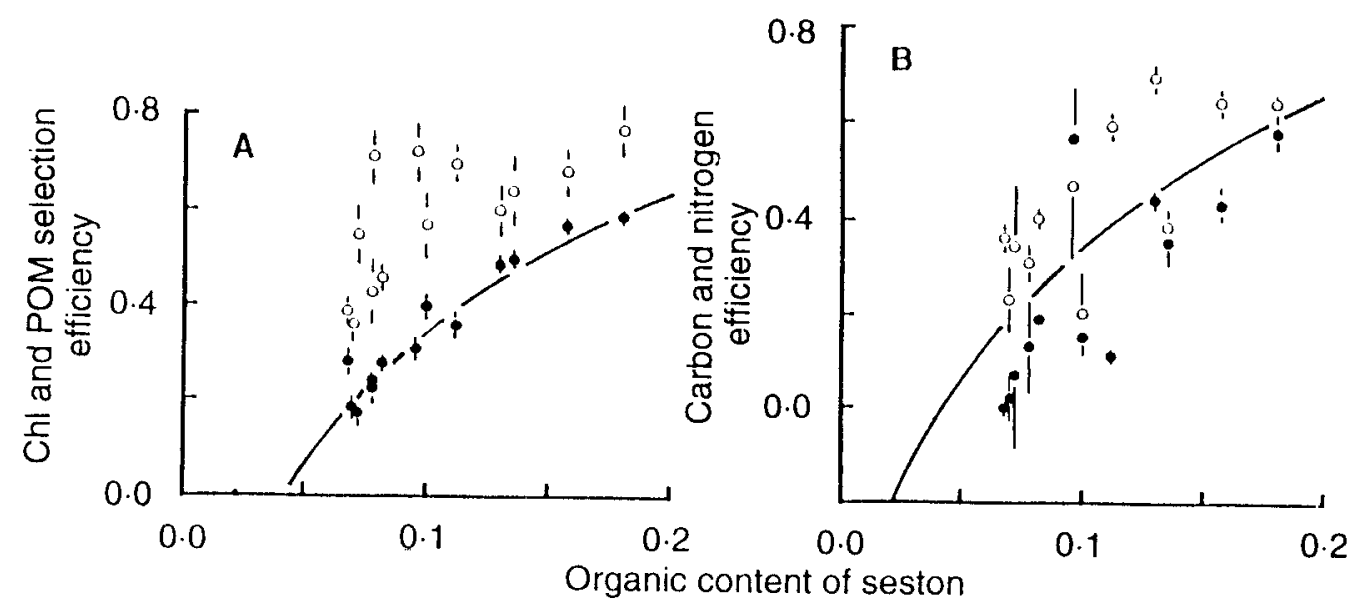

Figure 5. (A) Selection efficiency based on total organic matter $(\bullet)$ and chlorophyll $a$ ( ) in relation to the organic content of seston (f). Points are means $\pm S D$. (B) Selection efficiency based on particulate (-) organic carbon and (') nitrogen as a function of the organic content of seston. Points are means $\pm S D$. Curve plotted in both figures corresponds to a second degree polynomial function fitted to original values of selection efficiency based on total organics (see Table 3). It has been included for comparison.

On the other hand, multiple regression analysis revealed a rather complex dependence of $\mathrm{SE}_{\mathrm{o}}$ on dietary factors (Table $3 \mathrm{~B}$ ). Both $\mathrm{f}$ and $\mathrm{f}^{2}$ were retained in the model, accounting for the curvilinear relationship between $\mathrm{SE}_{o}$ and $\mathrm{f}$, with a peaking efficiency at $\mathrm{f}=0 \cdot 2$. The effect of TPM (positive in this case) was also statistically significant, but it accounted for a relatively minor proportion of variance in $\mathrm{SE}_{0}$. Overall, $\mathrm{SE}_{\mathrm{o}}$ was below $\mathrm{SE}_{\mathrm{chl}}$ (Figure 5A).

Mean selection efficiencies for carbon and nitrogen have been plotted against $f$ in Figure $5 \mathrm{~B}$. The curve relating $\mathrm{SE}_{0}$ values to the organic content (as estimated from equation in Table 3B) is given for comparison. In spite of relatively high variability in some cases, there was a consistent trend of higher selection for nitrogen and lower for carbon when compared with selection efficiencies for total organics.

The SNK test for multiple comparisons was performed on selection efficiency data to determine whether different substrates (POM, chl $a, P O C$ and PON) were differentially selected or not. Differences were found significant at $P=0.05$ (see Table 4 ) in all comparisons. The various estimates of selection efficiencies ranked as follows: $\mathrm{SE}_{\mathrm{chl}}>\mathrm{SE}_{\mathrm{N}}>\mathrm{SE}_{\mathrm{o}}$ $>\mathrm{SE}_{\mathrm{C}}$.

\section{Rate of organic ingestion}

Rates of organic ingestion (OIR) were dependent on the organic content of seston and, unlike total ingestion rates (Figure 4D), on particulate matter concentration as well (Figure 6A). Obviously, the fact that organic ingestion increased with rising particle concentration in a range where total ingestion was kept almost constant reflected the 
Table 3. Multiple-regression equations relating $(A)$ selection efficiency based on chlorophyll a $\left(S E_{\text {chl }}\right)$ and $(B)$ selection efficiency based on organic matter $\left(S E_{o}\right)$ to the organic content of seston $(f$ and $f)$, total particulate matter (TPM:mg $l^{-1}$ ), and the corresponding interaction terms (fxTPM and $\left.f^{2} x T P M\right)$.

(A)

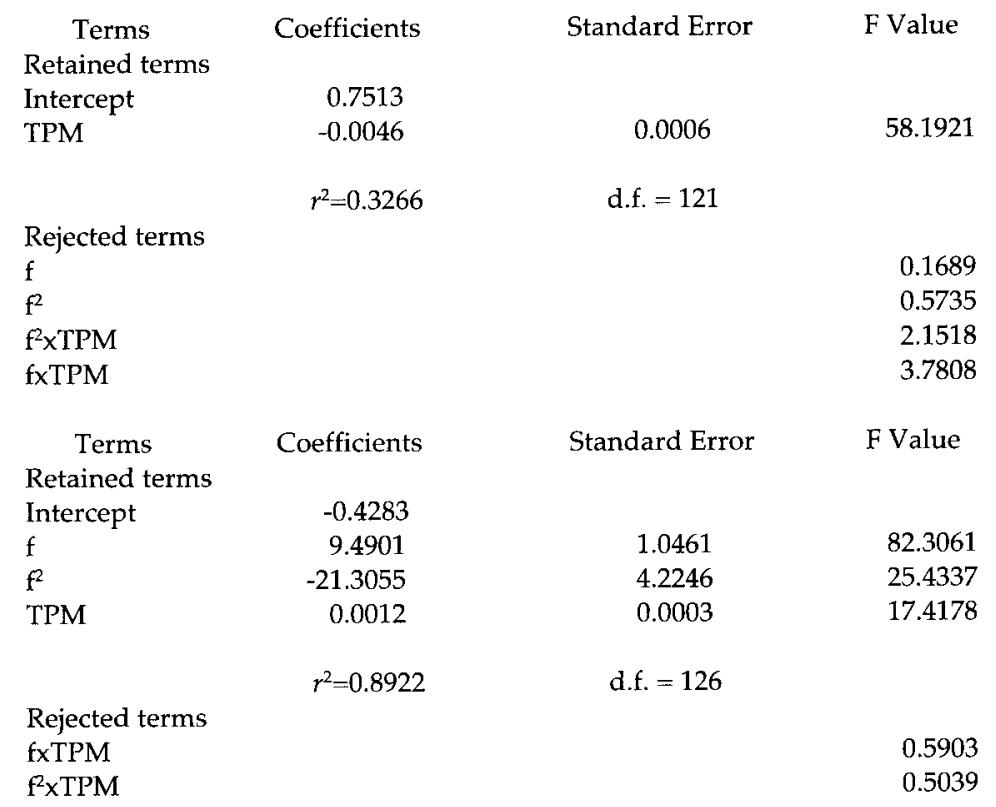

food enrichment resulting from preingestive selection. As selection efficiency increased with increasing quality of filtered matter, the positive effect of TPM on OIR was more pronounced with food of high organic content.

Table 4. Student-Newman-Keuls test applied to selection efficiency data for testing differences between different substrates: chl a $\left(S E_{c h l}\right), P O M\left(S E_{0}\right), P O C\left(S E_{C}\right)$ and $P N\left(S E_{N}\right)$.

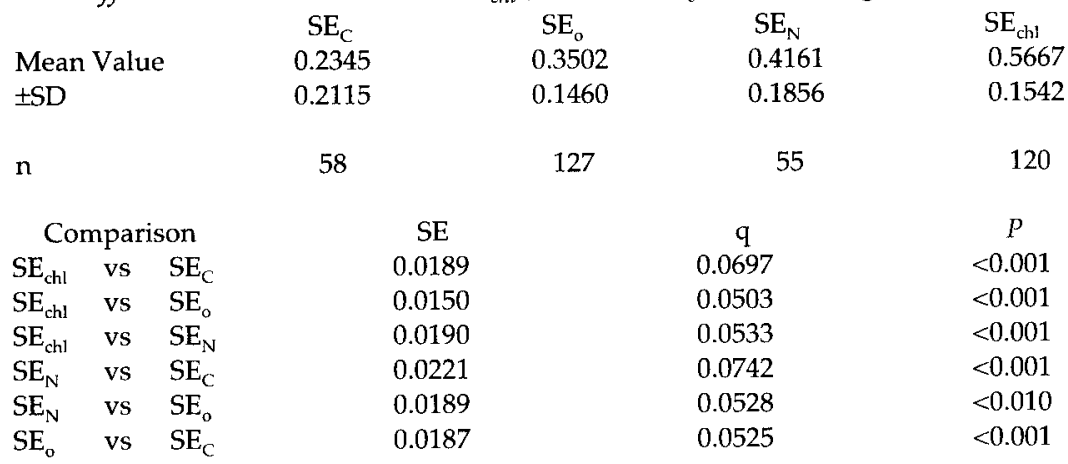




\section{Absorption efficiency and absorption rate}

Various authors have described absorption efficiency (AE) as an exponential function of food quality (Bayne et al., 1987, 1993; Navarro et al. 1991). Present estimates of food quality corresponded to the organic content of ingested ration (i), and so, we have expressed $\mathrm{AE}$ as an exponential asymptotic function of this variable (Figure 7). The fitted equation was (parameters are given \pm standard deviation):

$$
\mathrm{AE}=0.9500( \pm 0 \cdot 0351)\left(1-\mathrm{e}^{(-6.7253( \pm 0 \cdot 9542)(\mathrm{i}-0 \cdot 0072( \pm 0 \cdot 0117))}\right), r^{2}=0 \cdot 861 \mathrm{~N}=126 \text {. }
$$

In this equation, 0.9500 is the asymptotic (maximum) absorption efficiency, 6.7253 is the rate at which that maximum is approached with increasing $i$, and 0.0072 is the $i$ value at which absorption efficiency equals zero.

To check the possibility of carbon and/or nitrogen being differentially absorbed as compared with total organics, individual absorption efficiency values for $C\left(\mathrm{AE}_{\mathrm{C}}\right)$ and $N\left(A E_{N}\right)$ were expressed as linear functions of overall $A E$. Fitted equations were (slopes are given $\left.\pm \mathrm{CI}_{95 \%}\right)$ :

$$
\begin{aligned}
& \mathrm{AE}_{\mathrm{C}}=-0.065+0.948( \pm 0 \cdot 194) \mathrm{AE}, r^{2}=0 \cdot 442, \mathrm{~N}=32, \\
& \mathrm{AE}_{\mathrm{N}}=0.227+0.764( \pm 0 \cdot 108) \mathrm{AE}_{r} r^{2}=0 \cdot 627, \mathrm{~N}=32
\end{aligned}
$$

Comparison of data points revealed that $\mathrm{AE}_{\mathrm{N}}$ was, in general, higher than $\mathrm{AE}_{\mathrm{C}}$. However, differences between slopes were not found to be statistically significant $(P>0.05)$ due to the high variability exhibited by $\mathrm{AE}_{\mathrm{C}}$.

The slope of the regression for $\mathrm{AE}_{\mathrm{N}} \mathrm{Vs} \mathrm{AE}$ was, nevertheless, significantly lower than 1 and showed that $\mathrm{AE}_{\mathrm{N}}$ was generally higher than overall $\mathrm{AE}$.

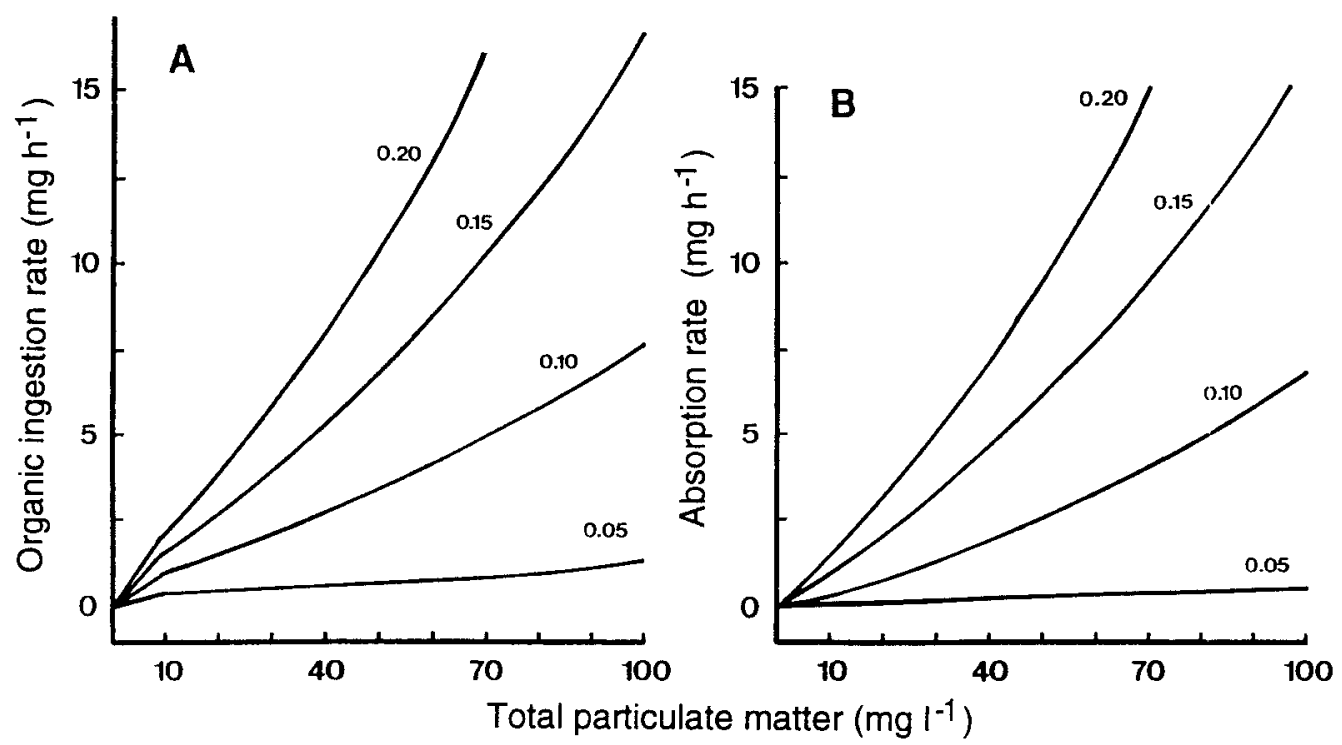

Figure 6. (A) Rates of organic ingestion (OIR: $\mathrm{mg} \mathrm{h}^{-1}$ ) and (B) rates of absorption (AR:mg $\mathrm{h}^{-1}$ ), estimated for different organic contents of seston $(\mathrm{f}=0.05$ to $0 \cdot 20)$ as a function of total particulate matter (TPM:mg 1-1 ). 


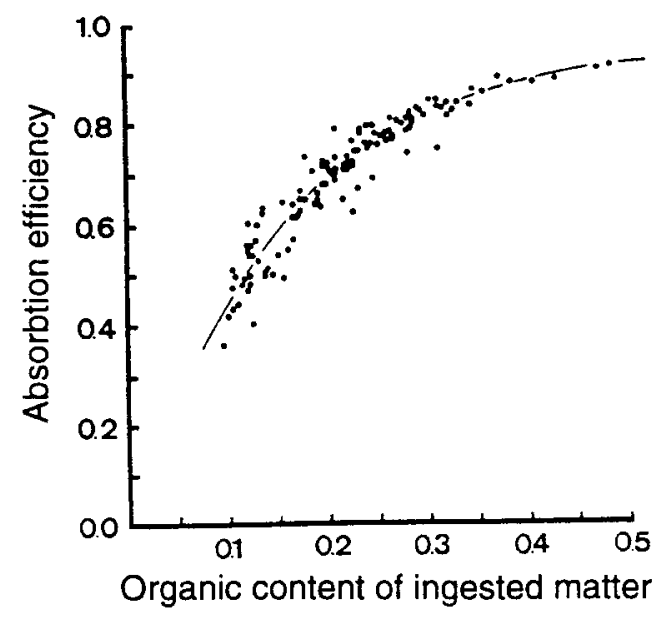

Figure 7. Absorption efficiency as a function of the organic content of ingested matter. Points represent individual values. The fitted equation is given in the text.

Absorption rate has been represented in Figure $6 \mathrm{~B}$ as a function of total particulate matter concentration and for a set of $\mathrm{f}$ values covering the range of organic contents recorded during these experiments. Trends are very similar to those shown by rates of organic ingestion, although in this case, the effect of the organic content of the seston is more pronounced, due to the additional effect of $i$ on AE. In fact, for a given TPM value, differences in absorption are greater in the lower range of $f$ values, which is the consequence of the rapid decline of $\mathrm{AE}$ at $\mathrm{i}$ values lower than $0 \cdot 15$.

\section{Simulation of variable field conditions}

In the field, variations in food quantity and quality are sometimes closely related, although the dependence between these variables is likely to change both in the spatial and temporal scales. Figure 8 is a simulation of the effect that resuspension of bottom materials with three different organic contents would exert on the rate of absorption, and hence, on energy acquisition. The solid line represents the absorption rate values that would result from substituting on the series of physiological equations previously presented in this section, TPM values ranging from 1 to $100 \mathrm{mg} \mathrm{l}^{-1}$ and their corresponding $f$ values as predicted by the equation fitted to the experimental data: $f=0 \cdot 3612$ $\mathrm{TPM}^{-372}$. This equation was then used, by simply varying the power value, to simulate different degrees of organic dilution with sediments of variable quality. Two power values, -0.222 and -0.523 , were chosen which for TPM equalling $100 \mathrm{mg}^{1-1}$ resulted in doubling and halving the organic content predicted by the original equation. Broken and dotted lines represent AR values that would result under those two hypothetical scenarios of improved and worsened qualities, respectively.

Figure 8 clearly shows the great effect that quality of resuspended sediments may exert on the energy acquisition in cockles. Under the naturally occurring TPM and $f$ 


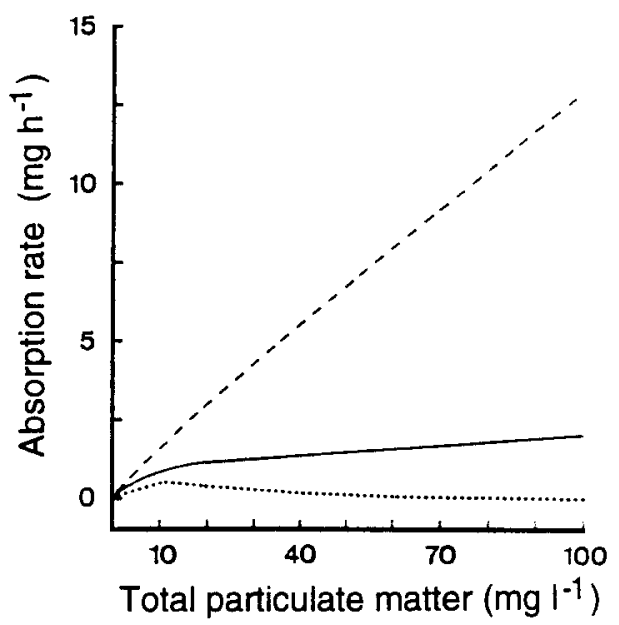

Figure 8. Rates of absorption (AR:mg $\mathrm{h}^{-1}$ ) as a function of seston concentration. Different lines result from simulating different degrees of organic dilution by resuspended sedimentary matter. The solid line corresponds to field conditions recorded in this study, where organic content was found to decrease with rising seston concentration according to the expression: $f=0.3612 \mathrm{TPM}^{-0.372}$. Estimation of absorption rates that would have resulted if the power value in the above expression had been -0.523 and $-0 \cdot 222$, are represented by dotted and broken lines, respectively (see text for explanation).

changes observed in this work, AR kept almost constant through all conditions. A potential increase in the organic content of resuspended matter would make AR positively dependent on TPM, whereas an hypothetical decrease would lead to low and declining absorption rates.

\section{DISCUSSION}

The aim of this study was to determine the way in which physiological processes underlying the feeding behaviour of cockles are affected by naturally fluctuating food conditions imposed by spring and neap tidal cycles in the Bay of Marennes-Oleron. The main effect exerted by tidal currents and wind on the food supply was resuspension of sedimentary matter from the bottom of the bay, resulting in marked short-term changes in both seston concentration and composition. Variations in the concentration of total particulate matter (TPM) and quality of seston defined in terms of organic content (f) were inversely correlated, organic content of food decreasing as concentration of suspended matter rises. This 'dilution' of suspended organic matter by resuspension of low organic matter from the bottom is a common event in most estuaries (Berg \& Newell, 1986; Smaal et al., 1986); the opposite phenomenon has seldom been documented (Fegley et al., 1992). Results obtained by analysis of chlorophyll $a$ and phaeopigment concentration in relation to particulate matter concentration suggest that resuspended organic matter was mainly detritic. Trends observed in the $\mathrm{C} / \mathrm{N}$ and $\mathrm{C}$ :chl ratio also support this hypothesis, both indexes increasing with rising particle concentration. 
Some previous works on the feeding physiology of Cerastoderma edule have shown a negative relationship between clearance rate and TPM, leading to the maintenance or even reduction of filtration rate at high seston concentration (Foster-Smith, 1975; Iglesias et al., 1992; Navarro et al., 1992, 1994). Trends observed in this study do not fit those observations. The slope of the power relationship between filtration rate and TPM was greater than one, implying that clearance rate tended to increase (slightly) with rising seston concentration. This finding agrees with extrapolation to lower $f$ values of the results obtained by Iglesias et al. (1992) for C. edule and Bayne et al. (1993) for Mytilus edulis, who predicted higher degrees of dependence between filtration rate and TPM for decreasing organic contents of the food. In this study, however, neither the organic content nor the interaction between TPM and $\mathrm{f}$ were found to exert significant effects on filtration rate (Table 1), due probably to the narrow range of variation of the organic content $(0 \cdot 07-0 \cdot 22)$ and its partial dependence on total particle concentration.

Ingestion rate, on the other hand, appeared strictly regulated. Advantages of regulating ingestion rate have been widely discussed in previous works (Navarro \& Iglesias, 1993; Navarro et al., 1994) regarding its effect on gross and net absorption efficiency. In relation to the mechanism of regulation, Foster-Smith (1975) proposed two strategies: a reduction in clearance rate, and/or alternatively, an increase in pseudofaeces production. This study and works by Iglesias et al. $(1992,1996)$ and Navarro et al. (1992) with C. edule and Cranford \& Gordon (1992) with Placopecten magellanicus, demonstrate that both mechanisms may operate simultaneously in some species. Under food conditions recorded in Marennes-Oleron, characterized by high concentrations of particulate matter of low organic content cockles controlled the quantity of food entering the digestive system mainly by varying the rate of pseudofaeces production.

Rejection rate depended on filtration rate and the organic content of filtered seston (Table 2), in such a way that the proportion of matter filtered by the gills that was rejected increased with increasing filtration rate towards an asymptotic value which depended on the quality of the food. For example, when organic content of the food was $\mathrm{f}=0.07$, this value was $95 \%$ whereas a $79 \%$ of asymptotic rejection corresponded to $f=0 \cdot 20$. This type of response resulted in different levels of ingestion depending on the organic content of seston, with higher ingestion rates corresponding to improved qualities. Energetic implications of this behaviour are relevant but a more precise evaluation requires consideration of preingestive selection and absorption processes.

The following rank was found for selection efficiencies of different substrates: $\mathrm{SE}_{\mathrm{chl}}>\mathrm{SE}_{\mathrm{N}}>\mathrm{SE}_{0}>\mathrm{SE}_{\mathrm{C}}$. In the field, suspended organic matter is composed of a complex mixture of particles: phytoplankton, zooplankton, bacteria, faecal pellets and detritus derived from plants as well as zooplankton remains. If particles of different origin are selected less efficiently than phytoplankton, selection efficiency for overall organic matter $\left(\mathrm{SE}_{\mathrm{o}}\right)$ will be necessarily lower when compared with selection efficiency for chlorophyll. This might also explain $\mathrm{SE}_{\mathrm{N}}$ being higher than $\mathrm{SE}_{\mathrm{o}}$ and $\mathrm{SE}_{\mathrm{C}}$ since phytoplankton $\mathrm{C} / \mathrm{N}$ ratio is usually lower than the $\mathrm{C} / \mathrm{N}$ index of detrital matter. On the other hand, pseudofaeces are produced embedded in mucus, which is voided together with rejected particles. Organic enrichment of pseudofaeces with this endogenous material would cause a reduction in selection efficiency indexes based on total organics, 
while it is not expected to affect indexes based in chlorophyll $a$. More specific studies are required for establishing mucus production and composition in order to determine gross selection efficiencies for different components of the food. This would allow establishing the type of particles being selected and how efficiently the processes are taking place throughout the wide range of conditions that cockles may face in their natural environment.

Selection efficiencies for chlorophyll $a$ was negatively affected by particle concentration (Table 3A). This result points towards a progressive loss of efficiency in the sorting process as increasing quantities of filtered matter are being processed by gills and palps. A decreased ability in sorting starch particles and Isochrysis galbana cells, due to saturation at high concentrations of kaolin has been reported by Urban \& Kirchman (1992) in Crassostrea virginica. However, the increase in kaolin concentration did not affect the quantity of chl $a$ filtered or rejected by the oysters. This information added to results obtained in investigations with $C$. edule where selection of phytoplanktonic cells in mixed diets was found to be independent on TPM (Iglesias et al., 1996), leads us to conclude that the observed loss of efficiency is an unusual effect that only occurs at extremely high concentrations of suspended matter (TPM $>40 \mathrm{mg} \mathrm{l}^{-1}$ ).

The dependence found in this work between $\mathrm{SE}_{\mathrm{o}}$ and $\mathrm{f}$ showed a trend similar to that found by Iglesias et al. (1992) in the same range of organic contents, although values obtained in this study are, on average, higher. Positive dependence between $\mathrm{SE}_{\mathrm{o}}$ and $\mathrm{f}$ at reduced values of food organic content is a typical feature which may be interpreted as the result of mucus contribution to pseudofaecal matter, since mucus would constitute an increasing proportion of rejected organic matter under conditions of decreasing quality of filtered particles. As found for $\mathrm{SE}_{\mathrm{chl}}$, the negative effect of high TPM on sorting efficiency would be expected to similarly affect selection efficiency of overall organics. Multiple regression analysis showed, though, that $\mathrm{SE}_{\mathrm{o}}$ was positively affected by TPM. The discrepancy might be explained if the contribution of mucus to pseudofaecal matter were proportionately less important as more matter is rejected. This might overcome the negative effect of high particle loads on the sorting ability of cockles which has been evidenced on the basis of chlorophyll a selection efficiency, making $\mathrm{SE}_{\mathrm{o}}$ positively dependent on particle concentration. This positive effect of increasing TPM on $\mathrm{SE}_{\mathrm{o}}$ however, is not enough to counteract the strong effect that decreasing organic content exerts on the $\mathrm{SE}_{\mathrm{o}}$.

Organic ingestion rate in C. edule appeared highly dependent on the organic content of filtered matter, which was a consequence of simultaneously higher ingestion rates of total matter and higher selection efficiencies for enhanced food quality. It seems clear that the rate of food acquisition by cockles is under a complex set of controls at the preingestive level, leading to maximum food intake at conditions from which maximum energetic gain may be obtained. This behaviour has been previously described for C. edule by Navarro et al. (1994) and Ibarrola et al. (1994).

The utilization of energy contained in ingested food is dependent on the absorption efficiency. Observed absorption efficiency values were clearly higher than those obtained in any previous experiment using natural sediment as food and are even higher than absorption efficiencies recorded with diets based on phytoplankton. This suggests 
that suspended organic matter in the Bay of Marennes-Oleron is highly digestible, at least during the time the experiments were conducted. This organic matter in suspension was mainly of detritic origin; digestibility of detritic matter has been shown to be highly variable depending on the ageing time, origin of the detritic matter and bivalve species under study, but mean values of $\mathrm{AE}$ as high as $84 \%$ were reported by Cranford \& Grant (1990) for Placopecten magellanicus fed aged kelp detritus. We hypothesize that a large proportion of the detritic matter in Marennes-Oleron may be derived from resuspension of pseudofaeces and faeces produced by dense population of bivalves inhabiting this area. This type of detritus may thus be composed of partially degraded and pre-digested organic matter and thus, digestibility could be improved.

The kind of dependence between absorption efficiency and the organic content of ingested matter reported in the present work has been previously described in studies where natural sediment was used as a component of food, for diverse bivalve species (Mercenaria mercenaria: Bricelj \& Malouf, 1984; Mytilus edulis: Bayne et al., 1987, 1993; Navarro et al., 1991; Ruditapes philippinarum: Goulletquer et al., 1989; Placopecten magellanicus: Cranford \& Grant, 1990) and demonstrates the extent to which absorption may be affected by 'dilution' of the organic matter with mineral particles.

Nitrogen absorption efficiency was, as a rule, higher than carbon absorption efficiency although we could not demonstrate statistically significant differences. Since for AE equalling 1 all components must be absorbed with the maximum efficiency, differences between $\mathrm{AE}_{\mathrm{C}}$ and $\mathrm{AE}_{\mathrm{N}}$ would be expected to become more evident for decreasing absorption efficiency of overall organic matter. Lack of recordings of $\mathrm{AE}_{\mathrm{C}}$ and $\mathrm{AE}_{\mathrm{N}}$ for overall $\mathrm{AE}$ values smaller than 0.5 in the present work precludes definitive conclusions regarding this point. In this sense, Grant \& Cranford (1991), who reported significantly higher absorption efficiencies for nitrogen than for carbon or organic matter in $P$. magellanicus, found that differences were, in effect, comparatively smaller in diets composed of Chaetoceros cells, where organic content was high, than with diets based on natural sediment of low organic content (below 0.2).

Nitrogen was found to be more readily absorbed than overall organic matter, however, since the slope of $\mathrm{AE}_{\mathrm{N}} \mathrm{vs} \mathrm{AE}$ was found to be different from 1 at $P=0 \cdot 05$. Observed higher absorption efficiencies for nitrogen than for overall organic matter may result from: (1) higher gross absorption efficiency for proteins than for other biochemical components; (2) a reduced nitrogen content in the digestive secretions added to the faeces. Elemental composition of the metabolic faecal losses in Placopecten reported by Cranford \& Grant (1990) suggested, however, that C/N ratio may be fairly low (C) $\mathrm{N}=7 \cdot 75$ ), so this information would support the first of the hypotheses proposed. Recently, Bayne et al. (1993) have suggested that elemental AE may be sensitive to the balance of biochemical components in the diet. Further research is needed to resolve these types of relationships. Whatever the reasons, a relatively high $\mathrm{AE}_{\mathrm{N}}$ is a valuable characteristic for animals living under feeding conditions such as those reported in this study (average $C / N=10 \cdot 296$ ), where restrictions to bivalve growth might come from the low nitrogen content of detrital matter.

Under field conditions bivalves usually face important changes in both the quantity and quality of the seston. As a rule, high organic contents occur at low seston concentrations and as particle load rises there is a concomitant decrease in the organic content of 
the seston. This is specially evident when the increase in particle concentration is caused by resuspension of sedimentary matter of lower organic content (Goulletquer et al., 1989; Razet et al., 1990). Comparison of the three lines shown in Figure 8 highlights the different effects exerted by an increase in TPM on absorption rate depending on the quality of suspended matter. For food conditions recorded in May 1992 in the Bay of Marennes-Oleron, absorption rate was virtually independent of particle concentration. Under these circumstances maximum benefit was taken from moderately efficient selection processes by maintaining high filtration and rejection rates. Quality of ingested matter was thus significantly improved compared with filtered matter, and consequently, absorption processes could operate efficiently enough so as to keep absorption rate nearly constant, in spite of decreasing qualities associated with increasing concentration of suspended particles. An hypothetical increase in the organic content of resuspended sediments would make absorption rates positively dependent on TPM. High organic ingestion rates would result from improved food availability and selection processes operating very efficiently. Ingested matter would then be of high quality, and hence, efficiently absorbed. Resuspension of a bottom material of lower organic content than observed in this study would result in depressed absorption rates showing a negative dependence on TPM. In this case, maintenance of high rates of pseudofaeces rejection would not have any beneficial effect, since energy losses associated with mucus secretion would exceed the low enrichment achieved through sorting processes.

Sediment resuspension processes may thus, elicit important and variable effects on food acquisition and growth, depending on the intensity of resuspension events and the organic content of the resuspended fraction. This might explain the great variability of results obtained in diverse studies designed to test the effect of sediment on absorption and growth in bivalves ( Kiørboe et al., 1981; Bricelj \& Malouf, 1984; Grizzle \& Morin, 1989; Prins \& Smaal, 1989; Grant et al., 1990; Frechette \& Grant, 1991; Grant \& Thorpe, 1991).

Finally, we can conclude that quantification of rates of seston processing and food acquisition is essential for understanding the way bivalves are affected by environmental feeding conditions and the role they play on the dynamics of the ecosystem which they inhabit.

The authors wish to thank the IFREMER-URFA team for laboratory facilities and help given with setting of experiments, and all participants in the TROPHEE project for many stimulating discussions about these topics. We appreciate valuable comments and suggestions made by an anonymous referee. This work was funded by an EEC contract FAR AQ2500.

\section{REFERENCES}

Bayne, B.L., Hawkins, A.J.S. \& Navarro, E., 1987. Feeding and digestion by the mussel Mytilus edulis L. (Bivalvia: Mollusca) in mixtures of silt and algal cells at low concentrations. Journal of Experimental Marine Biology and Ecology, 111, 1-22.

Bayne, B.L., Hawkins, A.J.S., Navarro, E. \& Iglesias, J.I.P., 1989. Effects of seston concentration on feeding, digestion and growth in the mussel Mytilus edulis. Marine Ecology Progress Series, 55, $47-54$. 
Bayne, B.L., Iglesias, J.I.P., Hawkins, A.J.S., Navarro, E., Heral, M. \& Deslous-Paoli, J.-M., 1993. Feeding behaviour of the mussel, Mytilus edulis: responses to variations in quantity and organic content of the seston. Journal of the Marine Biological Association of the United Kinga'om, 73, 813-829.

Berg, J.A. \& Newell, R.I.E., 1986. Temporal and spatial variations in the composition of seston available to the suspension feeder Crassostrea virginica. Estuarine, Coastal and Shelf Science, 23, 375-386.

Bricelj, V.M. \& Malouf, R.E., 1984. Influence of algal and suspended sediment concentrations on the feeding physiology of the hard clam Mercenaria mercenaria. Marine Biology, 84, 155-165.

Cranford, P.J. \& Gordon, D.C. Jr, 1992. The influence of dilute clay suspensions on sea scallop (Placopecten magellanicus) feeding activity and tissue growth. Netherlands Journal of Sea Research, 30, 107-120.

Cranford, P.J. \& Grant, J., 1990. Particle clearance and absorption of phytoplankton and detritus by the sea scallop Placopecten magellanicus (Gmelin). Journal of Experimental Marine Biology and Ecology, 137, 105-121.

Cranford, P.J. \& Hargrave, B.T., 1994. In situ time-series measurement of ingestion and absorption rates of suspension-feeding bivalves: Placopecten magellanicus. Limnology and Oceanography, 39, 730-738.

Dame, R.F., 1993. The role of bivalve filter feeder material fluxes in estuarine ecosystems. In Bivalve filter feeders in estuarine and coastal ecosystems processes (ed. R.F. Dame), pp. 245-269. Heidelberg: Springer-Verlag. [NATO ASI Series G: Ecological Sciences, vol. 33.]

Deslous-Paoli, J.-M., Lannou, A.-M., Geairon, P., Bougrier, S., Raillard, O. \& Heral, M., 1992. Effects of the feeding behaviour of Crassostrea gigas (bivalve molluscs) on biosedimentation of natural particulate matter. Hydrobiologia, 231, 85-91.

Fegley, S.R., MacDonald, B.A. \& Jacobsen, T.R., 1992. Short-term variation in the quantity and quality of seston available to benthic suspension feeders. Estuarine, Coastal and Shelf Science, 34, 393-412.

Foster-Smith, R.L., 1975. The effect of concentration of suspension on the filtration rates and pseudofaecal production for Mytilus edulis L., Cerastoderma edule (L.) and Venerupis pullastra (Montagu). Journal of Experimental Marine Biology and Ecology, 17, 1-22.

Frechette, M. \& Grant, J., 1991. An in situ estimation of the effect of wind-driven resuspension on the growth of the mussel Mytilus edulis L. Journal of Experimental Marine Biology and Ecology, 148, 201-213.

Goulletquer, P., Heral, M., Deslous-Paoli, J.-M., Prou, J., Garnier, J., Razet, D. \& Boromthanarat, W., 1989. Ecophysiologie et bilan énergétique de la palourde japonaise d'élevage Ruditapes philippinarum. Journal of Experimental Marine Biology and Ecology, 132, 85-108.

Grant, J. \& Cranford, P.J., 1991. Carbon and nitrogen scope for growth as a function of diet irı the sea scallop Placopecten magellanicus. Journal of the Marine Biological Association of the United Kingdom, 71, 437-450.

Grant, J., Enright, C.T. \& Griswold, A., 1990. Resuspension and growth of Ostrea edulis: a field experiment. Marine Biology, 104, 51-59.

Grant, J. \& Thorpe, B., 1991. Effects of suspended sediment on growth, respiration and excretion of the soft-shell clam (Mya arenaria). Canadian Journal of Fisheries and Aquatic Sciences, 48, 12851292.

Grizzle, R.E. \& Morin, P.J., 1989. Effect of tidal currents, seston, and bottom sediments on growth of Mercenaria mercenaria: results of a field experiment. Marine Biology, 102, 85-93.

Ibarrola, I., Iglesias, J.I.P. \& Navarro, E., 1994. Differential absorption of dietary biochemical components by cockles: enzymatic responses to variations in seston composition. La Rochelle, France: Symposium Relations Continent-zones Cotieres.

Iglesias, J.I.P., Navarro, E., Alvarez-Jorna, P. \& Armentia, I., 1992. Feeding, particle selection and absorption in cockles Cerastoderma edule (L.) exposed to variable conditions of food concentration and quality. Journal of Experimental Marine Biology and Ecology, 162, 177-198.

Iglesias, J.I.P., Urrutia, M.B., Navarro, E., Alvarez-Jorna, P., Larretxea, X., Bougrier, S. \& Heral, M., 1996. Variability of feeding processes in the cockle Cerastoderma edule (L.) in response to changes in seston concentration and composition. In press. 
Kiørboe, T., Møhlenberg, F. \& Nøhr, O., 1980. Feeding, particle selection and carbon absorption in Mytilus edulis in different mixtures of algae and resuspended bottom material. Ophelia, 19, 193-205.

Kiørboe, T., Møhlenberg, F. \& Nøhr, O., 1981. Effect of suspended bottom material on growth and energetics in Mytilus edulis. Marine Biology, 61, 283-288.

Lorenzen, C.J., 1967. Determination of chlorophyll and pheo-pigments: spectrophotometric equations. Limnology and Oceanography, 12, 343-346.

Lucas, M.I. \& Newell, R.C., 1984. Utilization of saltmarsh grass detritus by two estuarine bivalves: carbohydrase activity of crystalline style enzymes of the oyster Crassostrea virginica (Gmelin) and the mussel Geukensia demissa (Dillwyn). Marine Biology Letters, 5, 275-290.

Navarro, E. \& Iglesias, J.I.P., 1993. Infaunal filter-feeding bivalves and the physiological response to short-term fluctuations in food availability and composition. In Bivalve filter feeders in estuarine and coastal ecosystems processes (ed. R.F. Dame), pp. 25-56. Heidelberg: SpringerVerlag. [NATO ASI Series G: Ecological Sciences, vol. 33.]

Navarro, E., Iglesias, J.I.P. \& Ortega, M.M., 1992. Natural sediment as a food source for the cockle Cerastoderma edule (L.): effect of variable particle concentration on feeding, digestion and the scope for growth. Journal of Experimental Marine Biology and Ecology, 156, 69-87.

Navarro, E., Iglesias, J.I.P., Ortega, M.M. \& Larretxea, X., 1994. The basis for a functional response to variable food quantity and quality in cockles Cerastoderma edule (Bivalvia, Cardiidae). Physiological Zoology, 67, 468-496.

Navarro, E., Iglesias, J.I.P., Pérez-Camacho, A., Labarta, U. \& Beiras, R., 1991. The physiological energetics of mussels (Mytilus galloprovincialis Lmk.) from different cultivation rafts in the Ría de Arosa (Galicia, NW Spain). Aquaculture, 94, 197--212.

Newell, C.R. \& Shumway, S.E., 1993. Grazing of natural particulates by bivalve molluscs: a spatial and temporal perspective. In Bivalve filter feeders in estuarine and coastal ecosystems processes (ed. R.F. Dame), pp. 85-148. Heidelberg: Springer-Verlag. [NATO ASI Series G: Ecological Sciences, vol. 33.]

NeweII, R.I.E. \& Langdon, C.J., 1986. Digestion and absorption of refractory carbon from the plant Spartina alterniflora by the oyster Crassostrea virginica. Marine Ecology Progress Series, 34, 105 115.

Prins, T.C. \& Smaal, A.C., 1989. Carbon and nitrogen budgets of the mussel Mytilus edulis L. and the cockle Cerastoderma edule (L.) in relation to food quality. Scientia Marina, 53, 477-482.

Razet, D., Heral, M., Prou, J., Legrand, J. \& Sornin, J.-M., 1990. Variations des productions de biodepots (feces et pseudofeces) de l'huitre Crassostrea gigas dans un estuaire macrotidal: Baie de Marennes-Oléron. Haliotis, 20, 143-161.

Smaal, A.C., Verhagen, J.H.G., Coosen, J. \& Haas, H.A., 1986. Interaction between seston quantity and quality and benthic suspension feeders in the Oosterschelde, The Netherlands. Ophelia, 26, 385-399.

Stenton-Dozey, J.M.E. \& Brown, A.C., 1992. Clearance and retention efficiency of natural suspended particles by the rock-pool bivalve Venerupis corrugatus in relation to tidal availability. Marine Ecology Progress Series, 82, 175-186.

Stenton-Dozey, J.M.E. \& Brown, A.C., 1994. Short-term changes in the energy balance of Venerupis corrugatus (Bivalvia) in relation to tidal availability of natural suspended particles. Marine Ecology Progress Series, 103, 57-64.

Stuart, V., 1982. Absorbed ration, respiratory costs and resultant scope for growth in the mussel Aulacomya ater (Molina) fed on a diet of kelp detritus of different ages. Marine Biology Letters, 3, 289-306.

Urban, E.R. Jr \& Kirchman, D.L., 1992. Effect of kaolinite clay on the feeding activity of the eastern oyster Crassostrea virginica (Gmelin). Journal of Experimental Marine Biology and Ecology, 160, 47-60.

Villiers, C.J. de \& Hodgson, A.N., 1993. The filtration and feeding physiology of the infaunal estuarine bivalve Solen cylindraceus Hanley 1843. Journal of Experimental Marine Biology and Ecology, 167, 127-142. 